\title{
A prosztatadaganatos betegek sugárterápiájának mikroköltség-számítása
}

\author{
Zemplényi Antal Tamás ${ }^{1,4}$. Mangel László dr. ${ }^{2}$ - Kaló Zoltán dr. ${ }^{5,6}$ \\ Endrei Dóra dr. ${ }^{3,4}$. Boncz Imre dr. ${ }^{4}$ \\ Pécsi Tudományegyetem, ${ }^{1}$ Kancellária, Egészségügyi Gazdálkodási Igazgatóság, \\ ${ }^{2}$ Orvostudományi Kar, Klinikai Központ, Onkoterápiás Intézet, ${ }^{3}$ Orvostudományi Kar, Klinikai Központ, \\ ${ }^{4}$ Egészségtudományi Kar, Egészségbiztosítási Intézet, Pécs \\ ${ }^{5}$ Eötvös Loránd Tudományegyetem, Egészség-gazdaságtani Kutatóközpont, Budapest \\ ${ }^{6}$ Syreon Kutató Intézet, Budapest
}

\begin{abstract}
Bevezetés: A technológia fejlődése új lehetőségeket nyitott a prosztatadaganat sugárkezelése terén, ugyanakkor kevéssé ismert a korszerü technológia költsége. Célkitüzés: Jelen elemzés célja, hogy összehasonlítsa a háromdimenziós konformális sugárterápia, a normál- és hipofrakcionált intenzitásmodulált sugárterápia költségét lokalizált prosztatarákos betegek kezelésében. Módszer: A retrospektív költségelemzés egy hazai onkológiai centrum adatai alapján készült az egészségügyi szolgáltató szemszögéből. Az irradiáció időtartamát 20 beteg összesen 100 kezelési frakciójának egyedi mérése alapján határozták meg. Az egységköltségeket az intézmény kontrollingrendszere alapján számították ki. Eredmények: Egy frakció átlagos időtartama a hagyományos háromdimenziós konformális sugárterápia esetén 14,5 perc, intenzitásmodulált sugárterápia esetén képvezérelt eljárással 16,2 perc, míg képvezérelt eljárás nélkül 14 perc volt. A kezelés teljes költsége háromdimenziós konformális sugárterápia esetén 619 ezer forint, intenzitásmodulált sugárterápia esetén 933 ezer forint és hipofrakcionált intenzitásmodulált sugárterápia esetén 692 ezer forint volt. Következtetések: A már bizonyítottan költséghatékonyabb intenzitásmodulált és hipofrakcionált intenzitásmodulált sugárterápia alkalmazása nagyobb költséggel jár a szolgáltatók számára, ugyanakkor a jelenleg hatályos finanszírozás nem ösztönöz a hatékonyabb terápia alkalmazására. Orv. Hetil., 2016, 157(12), 461-468.
\end{abstract}

Kulcsszavak: prosztatarák, sugárterápia, hipofrakcionálás, költség és költségelemzés

\section{A microcosting study of radiation therapy of localized prostate cancer}

Introduction: Development of radiation technology provides new opportunities for the treatment of prostate cancer, but little is known about the costs of novel technologies. Aim: The aim of this analysis was to compare the costs of conventional three-dimensional radiation therapy to normal and hypofractionated intensity-modulated radiation therapy for the treatment of localized prostate cancer. Method: The cost-analysis was performed based on the data of a Hungarian oncology center from health care provider's perspective. Irradiation time was assessed from the data of 100 fractions delivered in 20 patients. Unit costs for each component were calculated based on actual costs retrieved from the accounting system of the oncology center. Results: Average treatment delivery times were 14.5 minutes for three-dimensional radiation therapy, 16.2 minutes for intensity-modulated radiation therapy with image-guided and 14 minutes without image-guided method. Expected mean cost of patients undergoing conventional three-dimensional radiation therapy, normal and hypofractionated intensity-modulated radiation therapy were 619000 HUF, 933000 HUF and 692000 HUF, respectively. Conclusions: Although normal and hypofractionated intensity-modulated radiation therapies have already been proven to be cost-effective, current reimbursement rates do not encourage healthcare providers to use the more effective therapy techniques.

Keywords: prostatic neoplasm, radiotherapy, dose hypofractionation, costs and cost analysis

Zemplényi, A. T., Mangel, L., Kaló, Z., Endrei, D., Boncz, I. [A microcosting study of radiation therapy of localized prostate cancer]. Orv. Hetil., 2016, 157(12), 461-468.

(Beérkezett: 2016. január 12.; elfogadva: 2016. február 4.) 


\section{Rövidítések}

$3 \mathrm{D}=$ háromdimenziós; $3 \mathrm{DCRT}=(3 \mathrm{D}$ conformal radiation therapy) háromdimenziós konformális sugárterápia; $\mathrm{BED}=$ (biological equivalent dose) biológiailag egyenértékű dózis; HF-IMRT = (hypofractionated intensity-modulated radiotherapy) hipofrakcionált intenzitásmodulált sugárterápia; IGRT = (image-guided radiotherapy) képvezérelt sugárterápia; IMAT $=$ (intensity-modulated arc therapy) intenzitásmodulált ívbesugárzás; IMRT = (intensity-modulated radiotherapy) intenzitásmodulált sugárterápia

Köszönhetően az utóbbi évek műszaki és számítástechnikai fejlődésének, az elmúlt két évtizedben a daganatos betegek sugárterápiás ellátása jelentősen megváltozott, újabb és újabb korszerü technológiák kerülnek bevezetésre a mindennapos klinikai gyakorlatba. Az ezredfordulóra széles körben elterjedt eljárássá vált az úgynevezett háromdimenziós CT-tervezés-alapú konformális sugárterápia (3D conformal radiation therapy-3DCRT). Az elmúlt évtizedben pedig egyre több központban váltak rutinná a képvezérelt besugárzási módszerek (imageguided radiotherapy - IGRT), az úgynevezett intenzitásmodulált sugárterápia (intensity-modulated radiotherapy - IMRT) vagy legújabban a dinamikus ívbesugárzás (intensity-modulated arc therapy - IMAT) [1, 2]. Mindezen technológiai forradalom persze a sugárterápiás szemlélet átalakulásával is együtt járt, a mellékhatások fokozott kockázata nélkül bátrabban alkalmazunk magasabb dózisokat, kombinált kezeléseket, illetve az úgynevezett frakcionálási gyakorlat is megváltozott. A hipofrakcionálás révén a fokozott precizitás birtokában egyszeri nagyobb dózisok kiszolgáltatása is lehetséges, összességében rövidebb kezelési időszak alatt [3-5].

A technológiai fejlődésnek komoly ára van, hiszen egy-egy speciális kezelés bekerülési költsége jóval magasabb, mint a hagyományos besugárzásoké $[6,7]$. Ilyen típusú sugárterápiás fejlesztés egyébiránt úttörő módon már Magyarországon is történt pár éve $[1,8]$, továbbá 2015-ben az európai uniós pályázatoknak köszönhetően az ország több városában telepítettek ilyen készülékeket. A korszerü technika elterjedése ugyanakkor megkívánja, hogy megvizsgáljuk a hagyományos, az elmúlt 1-2 évtizedben alkalmazott (háromdimenziós konformális) és az említett korszerú besugárzási módszereket, figyelembe véve a hatásosságot, az életminőséget, a költséget és a költséghatékonyságot. Az elemzés elvégzéséhez olyan betegségentitás vizsgálatát választottuk, amely igen gyakori és így népegészségügyi jelentőségű, ahol a korszerü sugárterápiás módszerek teljesen elfogadottak, és azok alkalmazása a gyógyítási eredmények javulását hozza ma- gával. Az IMRT egyik leggyakoribb felhasználási területe a lokalizált prosztatarák [9], így korábbi közleményünkben részletesen vizsgáltuk az IMRT és hipofrakcionált IMRT költséghatékonyságát a 3DCRT-hez viszonyítva [10], amelynek során megállapítottuk, hogy a korszerü technikák alkalmazása nemcsak költséghatékony, hanem a beteg életciklusát vizsgálva költségcsökkentő is.

A prosztatarák a nyugati világ legtöbb országában a férfiaknál az egyik leggyakoribb daganat. Magyarországon évente mintegy 4000 új esetet regisztrálnak [11], és egy évben több mint 1000 férfi hal meg prosztatarákban, ami az összes daganatos halálozás szempontjából a nyolcadik, a férfi daganatos halálozás tekintetében a negyedik helyen áll [12].

Jelen közleményben az egészségügyi szolgáltatók nézôpontjából kívánjuk bemutatni és összehasonlítani a háromdimenziós konformális sugárterápia (3DCRT), a normálfrakcionálású és egyelőre klinikai vizsgálat részeként a közeljövőben bevezetésre kerülő hipofrakcionált intenzitásmodulált sugárterápia (IMRT és HF-IMRT) költségét lokalizált prosztatarákos betegek kezelésében.

\section{Módszer}

Az adatok a Pécsi Tudományegyetem, Klinikai Központ Onkoterápiás Intézetéból származnak, ahol 2011-ben került telepítésre egy korszerú lineáris gyorsító sugárterápiás eszköz. A tanulási időszakot követően 2014-re már nagy gyakorlat (évi mintegy 150 beteg) alakult ki a prosztatarákos betegek kezelésében az új eszközzel, így a retrospektív adatgyújtés ebben az időszakban valósult meg. A 3DCRT-vel kezelt betegek adatai korábbi időszakból származnak, amikor az új eszköz még nem állt rendelkezésre. Ennek oka, hogy az új eszköz telepítését követően a kedvezőbb terápiás hatás miatt a betegeket már kizárólag az új készüléken látták el. Az elemzésben kizárólag olyan lokalizált prosztatadaganattal rendelkező betegek adatai kerültek figyelembevételre, ahol az onkoteam a sugárterápiát választotta első vonalbeli terápiának.

A sugárterápia költségének meghatározása mikroköltség-számítási módszerrel [13] történt, amelynek során meghatározásra került az erőforrás-felhasználás, az egészségügyi szolgáltatónál felmerülő költségelemek egységköltsége. Az erőforrás-felhasználást tevékenységalapú költségszámítási módszerrel határoztuk meg [14, 15]. Ennek keretében definiáltuk a sugárterápiás kezelés folyamatát, amit az 1. ábra tartalmaz. A folyamat a következő főbb lépésekből állt: konzultáció, kiegészítő vizsgálatok elvégzése, tervezési CT-vizsgálat, kontúro-

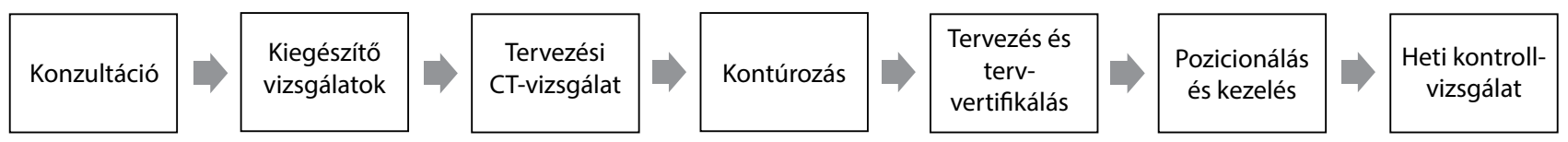

1. ábra

| A sugárterápiás ellátás folyamata 
zás, tervezés, tervverifikálás, pozicionálás és kezelés, heti kontroll. Minden költség forintban került kifejezésre.

A munkaidő-ráfordítási igény, illetve a diagnosztika igénybevételének gyakorisága (kismedencei MR-vizsgálat, csontszcintigráfia, natív CT-vizsgálat) a sugárterápiás szakorvosokkal és részben fizikusokkal folytatott interjúk alapján került meghatározásra. A sugárterápiás kezelés gépideje a 3DCRT és az IMRT vonatkozásában 20-20 beteg 5-5 kezelése alapján került kiszámításra. Az IMRT vonatkozásában megkülönböztettünk IGRT-vel és a nélkül végzett kezeléseket. Mindezeket figyelembe véve három frakciótípusra vonatkozóan határoztunk meg átlagos pozicionálási és kezelési időtartamokat: 3DCRT besugárzás, IMRT Rapidarc besugárzás, IMRT Rapidarc cone-beam CT-ellenőrzéssel (IGRT). A három frakciótípus alapján szimuláltuk a 3DCRT, a hagyományos frakcionálású IMRT és a hipofrakcionált IMRT teljes kezelési időtartamát.

A költségelemzésben a 3DCRT kezelési időtartamát Elekta készüléken, míg az IMRT és HF-IMRT kezelési időtartamait Novalis Tx rendszer alkalmazásával mértük.

Az egységköltségek meghatározásához a következő költségkategóriákat képeztük: igénybe vett diagnosztika, az élőmunka-költség munkaköri csoportonként (szakorvos, fizikus, asszisztens), sugárterápiás készülék üzemeltetési költsége, egyéb általános költségek és tőkeköltség.

A diagnosztika igénybevételének egységnyi költségét a 9/2012. (II. 28.) NEFMI rendeletben rögzített, az Orvosi Eljárások Nemzetközi Osztályozása alapján meghatározott kódhoz (OENO-kód) tartozó németpont-érték és az Országos Egészségbiztosítási Pénztár 2014-ben hatályos finanszírozási alapdíjának ( $1,5 \mathrm{Ft} /$ német pont) szorzataként vettük figyelembe.

Az élő munka költséget az Onkoterápiás Intézet sugárterápiás részlegén dolgozók munkaköri csoportokra bontott 2014. évi havi átlagos bértömege és havi átlagos munkaideje alapján határoztuk meg egy percre vetítve.

Az eszköz üzemeltetési költségei között a 2014. évi karbantartási díjat, a belső munkatársak és külső szolgáltató által végzett minőségbiztosítás költségét, illetve a sugárterápiás kezelőhelyiségre felosztott közüzemi költségeket vettük figyelembe. Meghatároztuk egyúttal a sugárterápiás készülékek éves hasznos üzemidejét, ami az eltérő karbantartási szükséglet miatt különbözik a 3DCRT és az IMRT vonatkozásában. A lehetséges éves üzemidő alapján meghatároztuk az egy percre jutó eszközhasználati költséget. Az elemzésben használt egységköltségek összegét az 1. táblázat tartalmazza. A közvetett költségek közé soroltuk a sugárterápiás tevékenységet végző egészségügyi dolgozók bérének azon részét, ami nem rendelhető közvetlenül beteghez a ráfordított munkaidő alapján. A közvetett költségek között jelenítettük meg továbbá az Onkoterápiás Intézet igazgatási és adminisztrációs költségeit, illetve az intézetre felosztott központi költségeket (overhead). A közvetett költségeket először a sugárterápiás tevékenységre osztottuk, majd a 2014-ben elvégzett összes kezelésszám alapján meghatá-
1. táblázat |Az erőforrás-felhasználás egységköltségei

\begin{tabular}{lrl}
\hline Megnevezés & Egységköltség & Mértékegység \\
\hline Élőmunka-költség & & \\
Sugárterápiás szakorvos & $80 \mathrm{Ft}$ & $\mathrm{Ft} /$ perc \\
Fizikus & $70 \mathrm{Ft}$ & $\mathrm{Ft} /$ perc \\
Asszisztens & $35 \mathrm{Ft}$ & $\mathrm{Ft} /$ perc \\
\hline
\end{tabular}

Diagnosztika

$\begin{array}{lrl}\text { Kismedencei MR (OENO: 34940) } & 30009 \mathrm{Ft} & \mathrm{Ft} / \mathrm{db} \\ \text { Csontszcintigráfia (OENO: 3523B) } & 7500 \mathrm{Ft} & \mathrm{Ft} / \mathrm{db} \\ \text { Natív CT-vizsgálat (OENO: 34460) } & 5715 \mathrm{Ft} & \mathrm{Ft} / \mathrm{db}\end{array}$

Sugárterápiás gépidő

3DCRT sugárterápiás gépidő

IMRT sugárterápiás gépidő

$275 \mathrm{Ft} \mathrm{Ft} /$ perc

HF-IMRT sugárterápiás gépidó

$461 \mathrm{Ft} \mathrm{Ft} /$ perc

$461 \mathrm{Ft} \mathrm{Ft} /$ perc

roztuk az elemzés szempontjából releváns készülékre (lineáris gyorsítóra) jutó költségarányt. Jelen elemzésben a közvetett költségeket a lineáris gyorsítók éves hasznos üzemideje és a frakciók átlagos időtartama alapján kalkulált lehetséges beavatkozásszám (frakció) alapján osztottuk fel, majd az egy betegre jutó közvetett költséget az átlagos frakciószám alapján határoztuk meg.

A tókeköltségek között a készülék árát, a szoftverek költségét (tervezőrendszer, Monte-Carlo algoritmus és verifikációs rendszer) vettük figyelembe. A 3DCRT-beavatkozás elvégzéséhez alkalmas eszköz bekerülési értéke mintegy 350 millió forint, míg az IGRT-vel ellátott IMRT-besugárzásra alkalmas lineáris gyorsító 600 millió forintba kerül. A megadott összegektól természetesen eltérhet az eszközök tényleges bekerülési ára az alkalmazott technikai kiegészítók, illetve a gyártók függvényében. Az elemzésben ezért a Pécsi Tudományegyetemen beszerzett készülékek árából kiindulva egy becsült, átlagos beszerzési érték került figyelembevételre. Mind az eszközök, mind a szoftverek vonatkozásában 10 éves hasznos élettartamot és az éves üzemidőt alapul véve meghatároztuk az egy percre jutó tókeköltség összegét. A tőkeköltséget a teljes kezelési ciklus alatt igénybe vett sugárterápiás gépidő alapján osztottuk fel egy betegre. A szakirodalomban számos egyéb megközelítés is ismert a közvetett költségek és a tőkeköltségek felosztására [13]. Jelen közleményben ugyanakkor terjedelmi okok miatt ezeket külön nem elemeztük. A magyar egészségügyi rendszer további részletes finanszírozási kérdései máshol kerülnek tárgyalásra [16-19].

\section{Eredmények}

\section{A sugárkezelés idôtartama}

A hagyományos 3DCRT-kezelésre alkalmas lineáris gyorsító alkalmazása során egy frakció átlagos időtartama 14,5 percet tett ki. Ebből átlagosan 6 perc volt a be- 


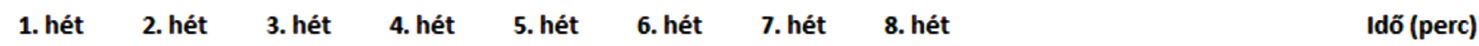

Hagyományos frakcionálás 3DCRT-vel, 37 frakció

\begin{tabular}{|c|c|c|c|c|c|c|c|}
\hline 14,5 & 14,5 & 14,5 & 14,5 & 14,5 & 14,5 & 14,5 & 14,5 \\
\hline 14,5 & 14,5 & 14,5 & 14,5 & 14,5 & 14,5 & 14,5 & 14,5 \\
\hline 14,5 & 14,5 & 14,5 & 14,5 & 14,5 & 14,5 & 14,5 & \\
\hline 14,5 & 14,5 & 14,5 & 14,5 & 14,5 & 14,5 & 14,5 & \\
\hline 14,5 & 14,5 & 14,5 & 14,5 & 14,5 & 14,5 & 14,5 & \\
\hline
\end{tabular}

Beteg fektetése és távozás $\quad 6$

Pozicionálás $\quad \mathbf{3 , 5 0}$

Kezelés 3DCRT-vel 5

3DCRT kezelés időtartama: $\quad 14,50$

Hagyományos frakcionálás IMRT-vel, Rapidarc-kal és heti IGRT-vel, 39 frakció

\begin{tabular}{|c|c|c|c|c|c|c|c|}
\hline 16,2 & 16,2 & 16,2 & 16,2 & 16,2 & 16,2 & 16,2 & 16,2 \\
\hline 16,2 & 14,0 & 14,0 & 14,0 & 14,0 & 14,0 & 14,0 & 14,0 \\
\hline 16,2 & 14,0 & 14,0 & 14,0 & 14,0 & 14,0 & 14,0 & 14,0 \\
\hline 16,2 & 14,0 & 14,0 & 14,0 & 14,0 & 14,0 & 14,0 & 14,0 \\
\hline 16,2 & 14,0 & 14,0 & 14,0 & 14,0 & 14,0 & 14,0 & \\
\hline
\end{tabular}

Beteg fektetése és távozás $\quad 6$

Cone-beam CT (IGRT) 2,2

Pozicionálás $\quad 4,2$

Kezelés IMRT Rapidarc-kal $\quad 3,7$

IMRT kezelés IGRT-vel $\quad 16,2$

IMRT kezelés IGRT nélkül $\quad 14,0$

Hipofrakcionálás IMRT-vel, Rapidarc-kal és napi IGRT-vel, 25 frakció

\begin{tabular}{|c|c|c|c|c|}
\hline 16,2 & 16,2 & 16,2 & 16,2 & 16,2 \\
\hline 16,2 & 16,2 & 16,2 & 16,2 & 16,2 \\
\hline 16,2 & 16,2 & 16,2 & 16,2 & 16,2 \\
\hline 16,2 & 16,2 & 16,2 & 16,2 & 16,2 \\
\hline 16,2 & 16,2 & 16,2 & 16,2 & 16,2 \\
\hline
\end{tabular}

Beteg fektetése és távozás $\quad 6,0$

Cone-beam CT (IGRT) 2,2

Pozicionálás $\quad 4,2$

Kezelés IMRT Rapidarc-kal $\quad 3,7$

HF-IMRT kezelés IGRT-vel $\quad 16,2$

2. ábra

| Frakcionálási sémák és kezelési időtartamok

teg előkészítése és távozása a sugárterápiás kezelőhelyiségből, 3,5 percet tett ki a beteg pozicionálása, míg a besugárzás átlagosan 5 percet vett igénybe.

A Pécsi Tudományegyetemen telepített új készülék a legkorszerúbb lineáris gyorsítók egyike, aminek alkalmazásához az Onkoterápiás Intézet belső sugárterápiás protokollt vezetett be. A lokalizált prosztatarák sugárkezelése kapcsán meghatározásra került az úgynevezett $\mathrm{kV}$-os cone-beam CT felhasználásával végzett IGRT-protokoll is, aminek célja, hogy a besugárzóhelyiségben közvetlenül a sugárterápia napi kiszolgáltatása előtt korrigálni lehessen a besugárzási terv esetleges pontatlanságait, annak érdekében, hogy a tervezettnek megfelelő dózis leadását lehessen biztosítani.

A beteg előkészítése és a kezelőhelyiségből való távozása az új készülék esetében megegyezett a korábban alkalmazott készüléknél mért időtartammal, ami 6 percet tett ki. Az IGRT-vel végzett kezelés áltagos időtartama a mért adatok alapján 2,2 perc volt, majd az ezt követő betegpozicionálás időtartama 4,2 percet tett ki. A Rapidarc-technikával végzett IMRT-besugárzás időtartama átlagosan 3,7 percig tartott. Az IMRT-sugárkezelés teljes időtartama tehát IGRT alkalmazása esetén 16,2 perc volt, míg a nélkül 14 perc. A prosztatarákos betegek esetén alkalmazott frakciók száma a daganat prognózisa és a kockázati besorolás alapján 35-40 közé esik. Jelen elem- zésben egy átlagos betegkohorszot feltételezve 8 hetes kezelési protokollal számoltunk, a 3DCRT esetén heti 5 alkalmat, az utolsó héten 2 besugárzást (összesen 37 frakciót), míg az IMRT esetében a dóziseszkaláció biztonságos lehetősége miatt heti 5 alkalmat és az utolsó héten 4 kezelést (összesen 39) figyelembe véve. IMRT esetén az első héten minden nap alkalmazásra került az IGRT, míg az ezt követő hetekben már csak a hét első napján. A teljes kezelési ciklusra vetített időtartam a 3DCRT esetében 537 perc volt, míg IMRT-vel 572 perc.

Hipofrakcionálás esetén még nagyobb precizitás biztosítása szükséges, ezért itt a jelenleg használatos protokoll szerint minden frakció esetén szükség van IGRT alkalmazására. Az egyes alkalmakkor leadott nagyobb sugárdózis (2,2-2,7 Gy/frakció) miatt ugyanakkor 5 héten át, heti 5 (összességében 25 ) besugárzással elérhető ugyanaz a dózismennyiség (biological equivalent dose - BED), mint a hagyományos dózisú (1,8-2 Gy/frakció) frakcionálás esetén [20-22]. Az IGRT-vel kiegészített HF-IMRT alkalmazásával a sugárkezelés teljes időtartama a szimuláció alapján lényegesen rövidebb időt, átlagosan 404 percet vesz igénybe. A vizsgált terápiás modalitások vonatkozásában alkalmazott frakcionálási sémákat, az egyes beavatkozások időtartamát és annak összetételét a 2. ábra mutatja be. 


\section{A sugárkezelés erôforrás-felhasználása}

Az egyes sugárterápiás modalitásokhoz tartozó eróforrás-felhasználás egy frakcióra vetített átlagos értékét a 2. táblázat tartalmazza.

Az IMRT és HF-IMRT esetében a tervezés és a verifikálás hosszabb idő́t vesz igénybe a hagyományos 3DCRT besugárzáshoz képest, mivel egyrészt a bonyolultabb besugárzási tervezés és dózisszámítás tovább tart, másrészt a verifikációs terv elkészítése, illetve kiértékelése és a fantom besugárzás végrehajtása is időigényes, amelyekre a magasabb sugárdózis leadását megelőző fokozott minőségbiztosítás miatt van szükség. A pozicionálás és kezelés során az erőforrás-felhasználásban jelentkező eltérés elsősorban a sugárkezelés teljes időtartamától és a frakciók számától függ, ami az IMRT esetén a legnagyobb, ugyanakkor ki kell emelni, hogy a HF-IMRT esetén az alacsonyabb gépidőigény ellenére a sugárterápiás szakorvosok munkaideje lényegesen nagyobb mértékben lekötött a napi IGRT miatt szükséges korrekciók, illetve margóigazítás miatt.

\section{A terápiás modalitások költségei}

A különböző sugárterápiás modalitások költségének öszszegzését a 3. táblázat tartalmazza. A sugárterápia összköltsége a 3DCRT vonatkozásában 619 ezer forint, míg az IMRT és HF-IMRT esetén 933 ezer forint, illetve 692 ezer forint. Az IMRT magasabb költségét a drágább sugárterápiás gépidő és a valamivel hosszabb kezelési időtartam magyarázza, illetve a készülék magasabb ára miatti nagyobb tőkeköltség. Hipofrakcionált technikával végzett besugárzás esetén ez a költségkülönbség lényegesen kisebb.

A sugárterápiás kezelés teljes folyamata szempontjából az összköltséget legnagyobb mértékben meghatározó tétel a pozicionálás és kezelés költsége, ami a 3DCRT esetén 194 ezer forintot, az IMRT esetén 323 ezer forintot, míg a HF-IMRT esetén 232 ezer forintot tett ki. Emellett jelentősen befolyásolja az összköltséget a tőkeköltség egy beteg kezelésére vetített összege is. Az IGRT-vel kiegészített IMRT elvégzésére alkalmas lineá-

2. táblázat |Az eróforrás-felhasználás adatai

\begin{tabular}{|c|c|c|c|c|c|}
\hline Folyamat lépései & Tevékenység leírása & Erőforrásigény & 3DCRT & IMRT & HF-IMRT \\
\hline \multirow[t]{2}{*}{ Konzultáció } & \multirow[t]{2}{*}{ Konzultáció a beteggel } & Asszisztensi munkaidő & 35 perc & 35 perc & 35 perc \\
\hline & & Sugárterápiás szakorvosi munkaidő & 35 perc & 35 perc & 35 perc \\
\hline \multirow{2}{*}{$\begin{array}{l}\text { Kiegészítő vizsgálatok } \\
\text { (staginghez, amennyiben } \\
\text { szükséges) }\end{array}$} & $\begin{array}{l}\text { Nyirokszerv-érintettség és } \\
\text { lokális kiterjedtség vizsgálata }\end{array}$ & Kismedencei MR, OENO: 34940 & 1 darab & 1 darab & 1 darab \\
\hline & Csontmetasztázis vizsgálata & Csontszcintigráfia, OENO: 3523B & 1 darab & 1 darab & 1 darab \\
\hline \multirow[t]{3}{*}{ Tervezési CT-vizsgálat } & $\begin{array}{l}\text { Betegrögzítő rendszer } \\
\text { beállítása }\end{array}$ & $\begin{array}{l}\text { Asszisztensi munkaidő } \\
\text { (átlagosan } 2 \text { fó) }\end{array}$ & 30 perc & 30 perc & 30 perc \\
\hline & \multirow{2}{*}{$\begin{array}{l}\text { Natív CT-vizsgálat és } \\
\text { beolvasás a tervezőrendszerbe }\end{array}$} & Natív CT-vizsgálat, OENO: 34460 & 1 darab & 1 darab & 1 darab \\
\hline & & Asszisztensi munkaidő (átlagosan 2 fó) & 50 perc & 50 perc & 50 perc \\
\hline \multirow[t]{2}{*}{ Kontúrozás } & $\begin{array}{l}\text { Kontúrozás: rizikószerv } \\
\text { kijelölése }\end{array}$ & Asszisztensi munkaidő & 40 perc & 40 perc & 40 perc \\
\hline & $\begin{array}{l}\text { Kontúrozás: céltérfogat } \\
\text { meghatározása }\end{array}$ & Sugárterápiás szakorvosi munkaidő & 30 perc & 30 perc & 30 perc \\
\hline \multirow[t]{5}{*}{ Tervezés és verifikálás } & $\begin{array}{l}\text { Besugárzástervezés, } \\
\text { dózisszámítás, szimuláció }\end{array}$ & Fizikusi munkaidő & 45 perc & 120 perc & 120 perc \\
\hline & \multirow[t]{2}{*}{ Tervértékelés } & Fizikusi munkaidő & 10 perc & 15 perc & 15 perc \\
\hline & & Sugárterápiás szakorvosi munkaidő & 5 perc & 15 perc & 15 perc \\
\hline & $\begin{array}{l}\text { Verifikációs terv elkészítése, } \\
\text { kiértékelés }\end{array}$ & Fizikusi munkaidő & 0 perc & 60 perc & 60 perc \\
\hline & Fantombesugárzás & Sugárterápiás gépidő & 0 perc & 20 perc & 20 perc \\
\hline \multirow[t]{5}{*}{ Pozicionálás és kezelés } & $\begin{array}{l}\text { Cone-beam CT-felvétel } \\
\text { (IGRT) }\end{array}$ & Sugárterápiás gépidő & 0 perc & 26 perc & 54 perc \\
\hline & \multirow{2}{*}{$\begin{array}{l}\text { Pozíciókorrekció } \\
\text { (és/vagy tervkorrekció, } \\
\text { margóigazítás) }\end{array}$} & Sugárterápiás gépidő & 130 perc & 166 perc & 106 perc \\
\hline & & Sugárterápiás szakorvosi munkaidő & 0 perc & 50 perc & 135 perc \\
\hline & \multirow[t]{2}{*}{ Besugárzás } & Sugárterápiás gépidő & 407 perc & 380 perc & 244 perc \\
\hline & & Asszisztensi munkaidő (2-3 fö/frakció) & 1,341 perc & 1,575 perc & 1,010 perc \\
\hline \multirow[t]{2}{*}{ Heti kontroll } & \multirow[t]{2}{*}{ Heti vizit } & Sugárterápiás szakorvosi munkaidő & 105 perc & 105 perc & 60 perc \\
\hline & & Asszisztensi munkaidő & 105 perc & 105 perc & 60 perc \\
\hline
\end{tabular}


3. táblázat |A sugárterápiás technikák költsége

\begin{tabular}{|c|c|c|c|c|}
\hline Sorszám & Tétel megnevezése & 3DCRT & IMRT & HF-IMRT \\
\hline 1. & Konzultáció & 4025 & 4025 & 4025 \\
\hline 2. & $\begin{array}{l}\text { Kiegészíto” } \\
\text { vizsgálatok }\end{array}$ & 37509 & 37509 & 37509 \\
\hline 3. & $\begin{array}{l}\text { Tervezési } \\
\text { CT-vizsgálat }\end{array}$ & 8515 & 8515 & 8515 \\
\hline 4. & Kontúrozás & 3800 & 3800 & 3800 \\
\hline 5. & Tervezés & 4250 & 24070 & 24070 \\
\hline 6. & $\begin{array}{l}\text { Pozicionálás } \\
\text { és kezelés }\end{array}$ & 194481 & 322660 & 232284 \\
\hline 7. & Heti kontroll & 12075 & 12075 & 6900 \\
\hline $8 .(1+\ldots 7)$ & $\begin{array}{l}\text { Összes közvetlen } \\
\text { költség }\end{array}$ & 264655 & 412654 & 317103 \\
\hline 9. & Közvetett költségek & 240741 & 266625 & 193160 \\
\hline 10. & Tókeköltség & 113738 & 253236 & 181386 \\
\hline 11. $(8+9+10)$ & $\begin{array}{l}\text { Sugárterápia } \\
\text { teljes költsége }\end{array}$ & 619135 & 932515 & 691649 \\
\hline
\end{tabular}

ris gyorsító esetében a tókeköltség több mint a duplája a 3DCRT elvégzésére alkalmas eszközhöz képest.

\section{Megbeszélés}

A daganatos megbetegedésekben szenvedők, illetve ezen belül a lokalizált prosztatarákos betegek sugárkezelésében jelentős fejlódés valósult meg az elmúlt évtizedekben. Az 1990-es években a 2D, majd 3D konformális sugárterápiával kezdve a 2000-es években megjelenő intenzitásmodulált és képalkotó-vezérelt technikán át egészen a koponyán kívüli stereotaxiás besugárzást lehetôvé tevő technológiáig számos fejlesztés támogatja a fejlett világ sugárterápiás kezeléseit. A modern sugárterápia pedig nemcsak a biztonságosabb, kevesebb mellékhatással járó kezelések kivitelezése szempontjából fontos, hanem lehetôvé teszi magasabb dózisok kiszolgáltatását és a kombinált kezelések jobb elviselhetőségét. A korszerú, új módszerek pedig prosztatarákos betegeknél érdemben javítják a betegek gyógyulási esélyeit [23], ugyanakkor egyre komplexebb technikát is igényelnek, amelyeknek magas a bekerülési költsége. Jelen közleményben megvizsgáltuk, hogy a korszerú és már bizonyítottan költséghatékony [10] IGRT-vezérelt IMRT, illetve HFIMRT alkalmazása milyen költséggel jár a kórházak és klinikák számára Magyarországon.

$\mathrm{Az}$ egészségügyi szolgáltatók szempontjából leginkább releváns megközelítés a marginális költségekben jelentkező eltérés vizsgálata. Ezt figyelembe véve az IMRT közvetlen költsége 148 ezer forinttal magasabb, mint a 3DCRT kezelésé, míg a HF-IMRT esetében mintegy 52 ezer forint összegú többletköltség keletkezik minden prosztatarákos beteg ellátása során. A közvetlen költségek körében mindhárom kezelési technika esetében a legmeghatározóbb költségokozó az egyes besu- gárzási frakciók időtartama és száma a teljes kezelési ciklus alatt. Ennek megfelelően a vizsgált technikák közötti eltérést a pozicionálás és kezelés végrehajtásának költségkülönbsége magyarázza. A hipofrakcionálás hatásosságát a prosztatadaganat esetében már több klinikai vizsgálat is igazolta $[24,25]$, így magasabb dózisok kiszolgáltatása révén a kezelési frakciók száma csökkenthető anélkül, hogy a terápia hatásossága romlana.

A sugárterápia finanszírozása Magyarországon kúraszerú elszámolás keretében zajlik, ami kórházi megközelítésben vizsgálva nem kedvez a frakciószám csökkentésének. A mérsékelt hipofrakcionálás esetén végzett 25 beavatkozásra csupán 3 kúra számolható el, míg a hagyományos technikával végzett, átlagosan 37 frakcióból álló sugárkezelés esetén 4 kúra számolható el. A hipofrakcionálás alkalmazása magasabb közvetlen költséggel jár, és alacsonyabb finanszírozás jár érte, miközben hatásosabb és költséghatékony.

A közvetett költségek összege a 3DCRT és az IMRT esetében közel megegyeznek, míg a HF-IMRT esetében ez közel 20\%-kal alacsonyabb a 3DCRT-hez képest. A betegre jutó közvetett költség összegét azonban jelentősen meghatározza az alkalmazott felosztási módszer, ami ettől jelentősen el is térhet. Ha például a közvetett költségeket a közvetlen költségek arányában osztottuk volna fel egy betegre, abban az esetben ez a HF-IMRT esetében magasabb lett volna.

A tőkeköltség alapvetően a beruházást (vagy annak visszapótlását) finanszírozó számára jelent megfontolandó kiadási tételt. A Magyarországon nemrégiben beszerzett korszerű eszközök többségében európai uniós forrásból kerültek finanszírozásra. Az IGRT-vel kiegészített IMRT alkalmazása lényegesen nagyobb beruházást igényel és az egy betegre vetített költsége a normálfrakcionálás esetén közel 139 ezer forinttal magasabb, mint a 3DCRT esetében. Hipofrakcionálás alkalmazása esetén ez a különbség a számításunk alapján kisebb (mintegy 68 ezer forint), mivel a kezelés kevesebb sugárterápiás gépidőt köt le (25 frakció a 37-tel szemben). Ez a hatás azonban csak abban az esetben érvényesül, ha a kevesebb kezelésszám miatt felszabaduló gépidőt egyéb beavatkozásokkal lehet feltölteni, ami azt igényli, hogy a korszerú technikával rendelkező sugárterápiás centrumok kapacitása megfelelően ki legyen használva.

Az elemzés korlátai között meg kell említeni, hogy a költségelemzés egy sugárterápiás centrum adataira épült. Ugyanakkor a költségadatok olyan intézményből származnak, ahol a sugárterápia több évtizede elérhető és jelentős számú betegforgalmat bonyolít, így reprezentatívnak tekinthetó a magyarországi centrumok vonatkozásában. Az elemzésben a besugárzás időtartamára vonatkozó adatokat olyan időszakból vettük (2014), amikor az intézménynek már többéves tapasztalata volt. A sugárterápia alkalmazásánál ugyanakkor létezik egy tanulási időszak, ami jelentősen hosszabb előkészítési időt is jelenthet. Ezt a hatást az elemzésben nem vettük figyelembe. 
Az elemzés másik korlátja, hogy csupán egy indikációra, a lokalizált prosztatarák kezelésére vonatkozik, így az elemzésben tett megállapítások nem általánosíthatók más indikációkra, illetve a sugárterápia teljes finanszírozására. A prosztatarák ugyanakkor a sugárterápia szempontjából az egyik leggyakrabban kezelt betegség, aminek ráadásul a népegészségügyi jelentősége egyre nagyobb.

Magyarországon az elmúlt időkben számos intézményben telepítésre kerültek korszerü sugárterápiás készülékek, így egyre nagyobb jelentőséget nyer a szolgáltatók azon igénye, hogy a drágább, ugyanakkor költséghatékonyabb beavatkozáshoz megfelelő finanszírozás is társuljon. A prosztatarák kezelésében a 3DCRThez viszonyítva már bizonyítottan költséghatékonyabb [10, 26-29] IMRT és HF-IMRT alkalmazása jelen költségelemzés alapján alacsonyabb fedezetet biztosít a szolgáltató számára, így a jelenlegi finanszírozás nem ösztönöz a hatékonyabb terápia alkalmazására. A lokalizált prosztatarák sugárterápiájának finanszírozása kapcsán fennálló ellentmondás feloldása és az új, hatásosabb terápiás technikák alkalmazása érdekében elkerülhetetlen a sugárterápiás HBCs klasszifikációjának módosítása, új beavatkozáskódok, HBCs-k és elszámolási szabályok bevezetése.

Anyagi támogatás: A közlemény megírása anyagi támogatásban nem részesült.

Szerzői munkamegosztás: Z. A. T., M. L., B. I.: A vizsgálat tervezése és lefolytatása. Z. A. T., K. Z.: Számszaki elemzések. Z. A. T., M. L., E. D., B. I.: Irodalomkutatás. M. L., K. Z., E. D., B. I.: A kézirat megszövegezése. A cikk végleges változatát valamennyi szerző elolvasta és jóváhagyta.

Érdekeltségek: A szerzőknek nincsenek érdekeltségeik.

\section{Irodalom}

[1] Szappanos, S., Farkas, R., Löcsei, Z., et al.: New methods in the treatment of localized prostate cancer: usage of dynamic arc therapy and $\mathrm{kV}$ cone-beam CT positioning. [Új módszerek a prosztatadaganatok sugárkezelésében: dinamikus ívbesugárzás és kilovoltos „cone-beam” komputertomográfiás ellenőrzés.] Orv. Hetil., 2014, 155(32), 1265-1272. [Hungarian]

[2] Major, T., Ágoston, P., Jorgo, K., et al.: Application of image-guided radiotherapy in external beam radiation of cancer patients. [Képvezérelt sugárterápia klinikai alkalmazása daganatos betegek külső besugárzásánál.] Magy. Onkol., 2012, 56(4), 258-265. [Hungarian]

[3] Kwok, Y., Yovino, S.: Update on radiation-based therapies for prostate cancer. Curr. Opin. Oncol., 2010, 22(3), 257-262.

[4] Macias, V., Biete, A.: Hypofractionated radiotherapy for localised prostate cancer. Review of clinical trials. Clin. Transl. Oncol., 2009, 11(7), 437-445.

[5] Aneja, S., Yu, J. B.: Comparative effectiveness research in radiation oncology: stereotactic radiosurgery, hypofractionation, and brachytherapy. Semin. Radiat. Oncol., 2014, 24(1), 35-42.
[6] Van de Werf, E., Verstraete, J., Lievens, Y.: The cost of radiotherapy in a decade of technology evolution. Radiother. Oncol., 2012, 102(1), 148-153.

[7] Ploquin, N., Dunscombe, P.: A cost-outcome analysis of imageguided patient repositioning in the radiation treatment of cancer of the prostate. Radiother. Oncol., 2009, 93(1), 25-31.

[8] Mangel, L., László, Z., Varga, Z., et al.: Stereotactic radiosurgery of abdominal cancer metastases. Report on the first successful extracranial radiosurgical intervention in Hungary. [Hasüregi daganatáttétek stereotaxiás sugárkezelése egy ülésben. Beszámoló az első hazai, koponyán kívüli sugársebészeti beavatkozásról.] Orv. Hetil., 2015, 156(39), 1593-1599. [Hungarian]

[9] Horwich, A., Hugosson, J., De Reijke, T., et al.: Prostate cancer: ESMO Consensus Conference Guidelines 2012. Ann. Oncol., 2013, 24(5), 1141-1162.

[10] Zemplényi, A. T., Kaló, Z., Kovács, G., et al.: Cost-effectiveness analysis of intensity-modulated radiation therapy with normal and hypofractionated schemes for the treatment of localised prostate cancer. Eur. J. Cancer Care, 2016 Jan 19. doi: 10.1111/ ecc.12430 [Epub ahead of print]

[11] National Institute of Oncology: Statistics of cancer registry. [Országos Onkológiai Intézet: Rákregiszter statisztika.] http:// www.onkol.hu/hu/rakregiszter-statisztika. [Hungarian]

[12] National Health Insurance Fund of Hungary (Hungarian acronym: OEP): Financing protocol for the diagnosis and treatment of prostate cancer. [Országos Egészségbiztositási Pénztár: A prosztatarák diagnosztikájának és kezelésének finanszírozási protokollja.] 2011. http://site.oep.hu/prot20110512/33 [Hungarian]

[13] Tan, S. S., Van Ineveld, B. M., Redekop, W. K., et al.: Comparing methodologies for the allocation of overhead and capital costs to hospital services. Value Health, 2009, 12(4), 530-535.

[14] Lievens, Y., van den Bogaert, W., Kesteloot, K.: Activity-based costing: a practical model for cost calculation in radiotherapy. Int. J. Radiat. Oncol. Biol. Phys., 2003, 57(2), 522-535.

[15] Zemplényi, A. T., Imre, L., Babarczy, B., et al.: International approaches to patient-level cost accounting. [Esetszintú kórháziköltség-számítás alkalmazása a nemzetközi gyakorlatban.] Egészségügyi Gazdasági Szle, 2014, 52(1), 20-25. [Hungarian]

[16] Boncz, I., Evetovits, T., Dózsa, C., et al.: The Hungarian Care Managing Organization Pilot Program. Value Health Regional., $2015,7,27-33$.

[17] Endrei, D., Molics, B., Ágoston, I.: Multicriteria decision analysis in the reimbursement of new medical technologies: real-world experiences from Hungary. Value Health, 2014, 17(4), 487489.

[18] Boncz, I., Sebestyén, A.: Financial deficits in the health services of the UK and Hungary. Lancet, 2006, 368(9539), 917-918.

[19] Boncz, I., Nagy, J., Sebestyén, A., et al.: Financing of health care services in Hungary. Eur. J. Health Econ., 2004, 5(3), 252-258.

[20] Koontz, B. F., Bossi, A., Cozzarini, C., et al.: A systematic review of hypofractionation for primary management of prostate cancer. Eur. Urol., 2015, 68(4), 683-691.

[21] Tree, A. C., Khoo, V. S., van As, N. J., et al.: Is biochemical relapse-free survival after profoundly hypofractionated radiotherapy consistent with current radiobiological models? Clin. Oncol., 2014, 26(4), 216-229.

[22] Zaorsky, N. G., Ohri, N., Showalter, T. N., et al.: Systematic review of hypofractionated radiation therapy for prostate cancer. Cancer Treat. Rev., 2013, 39(7), 728-736.

[23] Zelefsky, M. J., Kollmeier, M., Cox, B., et al.: Improved clinical outcomes with high-dose image guided radiotherapy compared with non-IGRT for the treatment of clinically localized prostate cancer. Int. J. Radiat. Oncol. Biol. Phys., 2012, 84(1), 125-129.

[24] Kuban, D. A., Nogueras-Gonzalez, G. M., Hamblin, L., et al.: Preliminary report of a randomized dose escalation trial for prostate cancer using hypofractionation. Int. J. Radiat. Oncol. Biol. Phys., 2010, 78(3), S58-S59. 
[25] Pollack, A., Walker, G., Horwitz, E. M., et al.: Randomized trial of hypofractionated external-beam radiotherapy for prostate cancer. J. Clin. Oncol., 2013, 31(31), 3860-3868.

[26] Zemplényi, A., Kaló, Z., Boncz, I., et al.: A microcosting study of radiation therapy in localized prostate cancer patients in a Hungarian tertiary oncology center. Value Health, 2015, 18(7), A354.

[27] Yong, J. H., Beca, J., McGowan, T., et al.: Cost-effectiveness of intensity-modulated radiotherapy in prostate cancer. Clin. Oncol., 2012, 24(7), 521-531.

[28] Hummel, S. R., Stevenson, M. D., Simpson, E. L., et al.: A model of the cost-effectiveness of intensity-modulated radiotherapy in comparison with three-dimensional conformal radiotherapy for the treatment of localised prostate cancer. Clin. Oncol., 2012, 24(10), el59-el67.

[29] Konski, A., Watkins-Bruner, D., Feigenberg, S., et al.: Using decision analysis to determine the cost-effectiveness of intensitymodulated radiation therapy in the treatment of intermediate risk prostate cancer. Int. J. Radiat. Oncol. Biol. Phys., 2006, $66(2), 408-415$.
(Zemplényi Antal Tamás, Pécs, Rákóczi u. 2., 7633 e-mail: zemplenyi.antal@pte.hu)

\section{MEGHÍl ó}

\section{A Szent János Kórház és Észak-budai Egyesített Kórházak Tudományos Bizottsága tisztelettel meghívja az érdeklődőket a következő tudományos ülésére.}

\section{Téma: Véráramfertőzések jelentősége, a megelőzés lehetőségei}

Időpont: 2016. március 31. (csütörtök) 14.00 óra

Helyszín: Szent János Kórház Auditóriuma - 1125 Budapest, Diós árok 1-3.

Üléselnök: Prof. Dr. Jánosi András

\section{Program:}

Dr. Rákay Erzsébet (Szent János Kórház), Dr. Szilágyi Emese (Országos Tisztifőorvosi Hivatal):

Perifériás érkatéterekkel összefüggő fertőzések megelözése

Dr. Rákay Erzsébet: Multirezisztens kórokozók, Cl. difficile elöfordulása a Szent János Kórházban - infekciókontroll helyzetkép 